\title{
Identification of strain types of some Beet necrotic yellow vein virus isolates determined in Northern and Central Parts of Turkey
} Nazli Dide Kutluk Yilmaz*

Ondokuz Mayis University, Faculty of Agriculture, Department of Plant Protection, 55139, Samsun, Turkey

\begin{abstract}
Beet necrotic yellow vein virus (BNYVV), the agent of rhizomania disease, causes severe economic losses in sugar beet fields in all over the world. The virus is transmitted by a plasmodiophorid vector, Polymyxa betae Keskin. Twenty soil samples, collected from sugar beet fields in northern and central parts of Turkey during surveys in 2004 and 2005 and known to be infested with viruliferous cultures of $P$. betae carrying BNYVV, were selected and used in this study. Sample selection was made according to symptom expression of beet seedlings in preliminary bait plant tests and locations of the soil samples that accurately represent the region from which they were taken. Total RNAs were extracted from sugar beet plants grown in these soils and used to amplify RNA-2 (nt. 19-1088) and RNA-3 (nt. 50-1268) of BNYVV by reverse transcription polymerase chain reaction (RT-PCR) method. Restriction fragment length polymorphism (RFLP) analysis of PCR-amplified products showed that most of BNYVV isolates studied were A-type strain, however, two isolates did not exactly match the band profile of A-type strain. Additionally, the presence of BNYVV RNA-5 component was investigated by RTPCR using the primers specific for P26 coding region. Four samples belonging to three provinces were found to be involving RNA-5 segment (20\%).
\end{abstract}

Accepted : 05.03.2016

Keywords: Sugar beet, rhizomania, RFLP, RT-PCR.

(C) 2016 Federation of Eurasian Soil Science Societies. All rights reserved

\section{Introduction}

Many soil-borne viruses are known to infect sugar beet (Beta vulgaris L.) worldwide. Among them, Beet necrotic yellow vein virus (BNYVV), which is the agent of rhizomania disease, is transmitted via the plasmodiophorid Polymyxa betae Keskin (Abe and Tamada, 1986) and causes severe economic losses in sugar beet fields in all over the world. BNYVV is type species of the genus Benyvirus and possesses a multipartite positive single stranded RNA genome, with four or five components (Tamada, 1999). RNA-1 and RNA-2 are required for replication, assembly and cell-to-cell movement, RNA silencing suppression and vector transmission of the virus. The RNA-3, which encodes for a 25kDa protein (p25), is responsible for pathogenicity and production of typical disease symptoms in sugar beet roots (Tamada et al. 1999; Chiba et al. 2008). RNA-4 coded p31 protein is more directly responsible for vector transmission and root-specific suppression of RNA silencing (Rahim et al. 2007; Peltier et al. 2008). The RNA-5 encodes 26kDa protein (p26) and is known to be an additional pathogenicity factor (Tamada et al. 1989). Also, BNYVV isolates

\footnotetext{
${ }^{*}$ Corresponding author.

Ondokuz Mayis University, Faculty of Agriculture, Department of Plant Protection, 55139, Samsun, Turkey

Tel.: +903623121919

E-mail address: nazlik@omu.edu.tr

e-ISSN: 2147-4249

DOI: http://dx.doi.org/10.18393/ejss.2016.3.241-248
} 
containing RNA-5 have been reported to be more pathogenic than RNA-5 lacking isolates (Tamada et al. 1996; Miyanishi et al. 1999).

Three major strain types of BNYVV have been identified using molecular analysis (Kruse et al. 1994; Koenig et al. 1995). The A-type strain, which is the most widespread (Schirmer et al. 2005), has been previously detected in Turkey (Kruse et al. 1994; Kutluk Yilmaz et al. 2007a), however the B-type strain is mainly found in Germany, France (Kruse et al. 1994; Koenig et al. 2008), Japan (Miyanishi et al. 1999), Iran (Sohi and Maleki, 2004) Belgium, the United Kingdom (Ratti et al. 2005) and China (Li et al. 2008). The P-type strain is closely related to the A type, but contains a fifth RNA and to date it has been recorded in Kazakhstan (Koenig and Lennefors, 2000), France (Schirmer et al. 2005) and the United Kingdom (Ward et al. 2007). The other BNYVV isolates containing RNA-5 segment have been suggested to be named as the J-type strain which possess two deletions at amino acid positions 77 and 227-229 in p26, compared to the P-type strain (Schirmer et al. 2005). The J-type widely distributed in Asia, especially in Japan (Tamada et al. 1989) and China (Li et al. 2008) whereas it was recorded in a field of Germany (Koenig et al. 2008). More recently, the Jtype RNA-5 containing BNYVV isolates were also detected in Turkey (Kutluk Yilmaz et al. 2016).

Although increases in sugar beet yields following some chemical treatments to control rhizomania disease were obtained, the use of these products is being phased out because of health hazards and adverse effects on the environment associated with their use. Alternatively, different methods have been tried for the control of rhizomania disease (Burketova et al. 1996; Wang et al. 2003; Akca et al. 2005; Akca et al. 2014). But, their efficiency not sufficient in eliminated BNYVV soil inoculum (Bragard et al. 2013). P. betae sporosori is able to persist in the soil for up to 25 years while remaining viruliferous (Abe and Tamada, 1986), therefore, the most reliable solution is use of resistant sugar beet cultivars.

In Turkey, rhizomania disease was reported in 1987 (Koch, 1987), and then it has been observed in most provinces where sugar beet is cultivated (Kaya, 2009; Kutluk Yilmaz and Arli-Sokmen, 2010; Yardimci and Culal-Kılıc, 2011; Kutluk Yilmaz et al. 2016).

In the current study, twenty BNYVV isolates were selected according to their symptom expression and geographic origin from the northern and central parts of Turkey. The BNYVV strain types were determined using reverse transcription-polymerase chain reaction (RT-PCR) and restriction fragment length polymorphism (RFLP) analyses, and the relationship between the phenotypic appearance of BNYVV on the sugar beet bait plants and strain types were investigated.

\section{Material and Methods}

\section{Bait plant technique}

In this study, twenty BNYVV isolates belonging to six provinces (Amasya, Cankiri, Corum, Kastamonu, Samsun and Tokat), out of 156 BNYVV-infected ones (Kutluk Yilmaz and Arli-Sokmen, 2010), were selected according to their symptom expression and geographic origin in order to be used in molecular studies (Figure 1, Table 1).

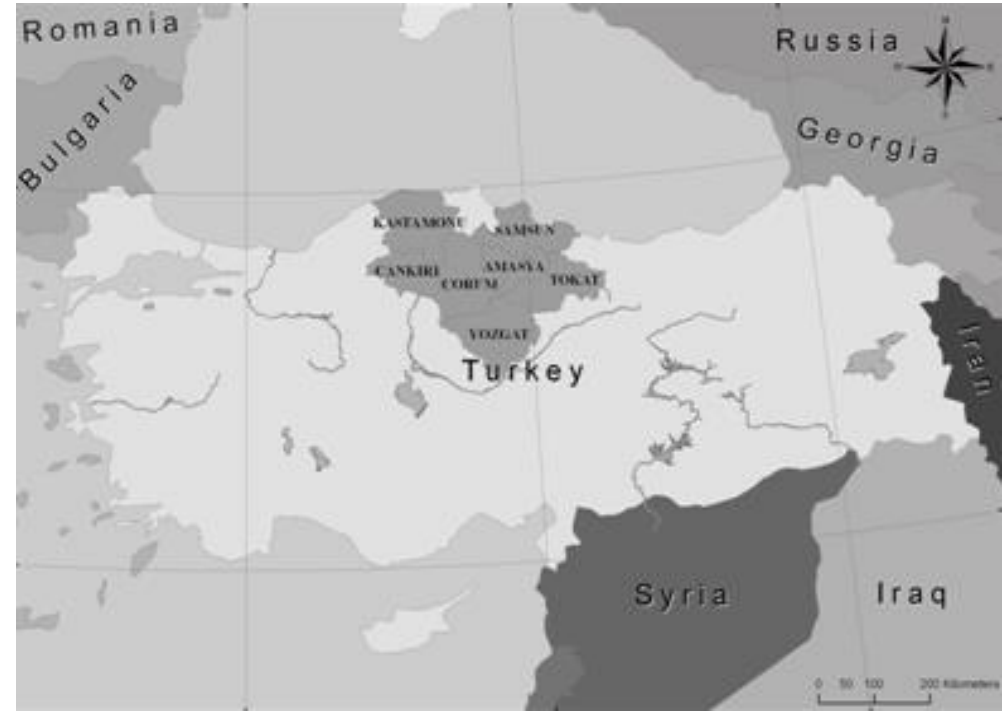

Figure 1. The dark colored inner area in the map of Turkey shows the region soil sampled. 
Table 1. Geographic origin and symptom expression of BNYVV isolates.

\begin{tabular}{llcc}
\hline Province & District & Isolate no & Infection phenotypes \\
\hline Corum & Iskilip & 114 & No visible symptom \\
Samsun & Bafra & 421 & \\
Tokat & Erbaa & 291 &
\end{tabular}

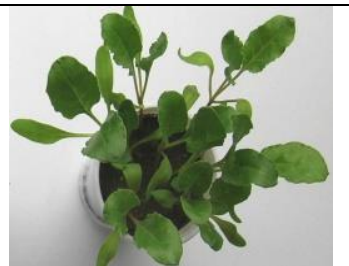

$\begin{array}{llcl}\text { Amasya } & \text { Centrum } & 178 & \text { Light chlorosis } \\ \text { Samsun } & \text { Kavak } & 40 & \\ \text { Tokat } & \text { Erbaa } & 103 & \\ & \text { Pazar } & 210 & \\ & \text { Zile } & 262\end{array}$

$\begin{array}{llc}\text { Amasya } & \text { Suluova } & 175 \\ & \text { Tasova } & 249 \\ \text { Kastamonu } & \text { Sarayovasi } & 176 \\ \text { Samsun } & \text { Vezirkopru } & 30 \\ \text { Tokat } & \text { Artova } & 325 \\ & \text { Niksar } & 202 \\ & \text { Niksar } & 275\end{array}$

Chlorosis
Cankiri Kizilirmak $\quad 164 \quad$ Leaf rolling+curling

Samsun $\quad$ Vezirkopru $\quad 85$

249

30

325

202

275

85

\section{Amasya}

Tasova

Corum

Osmancik

186

106

Green vein banding + distortion

Necrotic lesions

Tokat

Zile

150

Chlorotic lesions + chlorosis

Corum
Osmancik
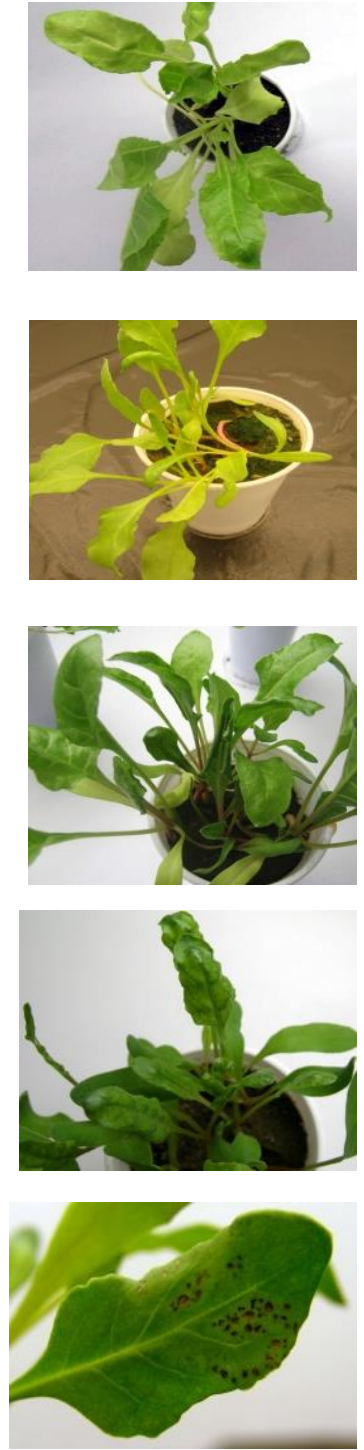

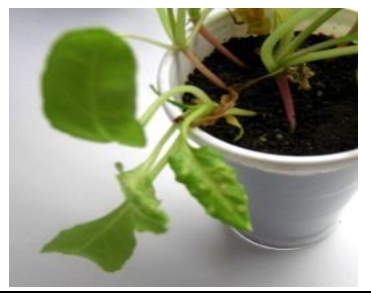

In the bait plant experiment, two $300 \mathrm{~mL}$ plastic pots were filled with each soil sample (20 samples) mixed with sterile sand ( 1 part soil: 1 part sand), and 10 sugar beet seeds of the rhizomania-susceptible (cv. Arosa) were sown in each pot for the bait plant test technique (Burcky and Buttner, 1985). The plants were grown under controlled conditions of 12 -h photoperiod, at $20^{\circ} \mathrm{C}$ (night) and $25^{\circ} \mathrm{C}$ (day) temperatures. All plants were equally watered generously every week with Hoagland's solution. After growing sugar beet seedlings six weeks, leaf symptoms on bait plants were recorded. In the harvest, plant roots were carefully washed in running top water. After that the combined roots of each pot were divided into two parts. One was used to test for the presence of BNYVV by ELISA and the other part for RNA extraction. Plant material was stored at - 
$20^{\circ} \mathrm{C}$ until used. In this study, soil samples infested with BNYVV P- type and B- type supplied by Claude Bragard (Universite Catholique de Louvain, Louvainla-Neuve, Belgium) was used as a reference material.

\section{Enzyme linked immunosorbent assay (ELISA)}

The bait plants were tested by double-antibody sandwich (DAS)-ELISA according to Clark and Adams (1977) using a specific polyclonal antiserum (Bioreba AG, Switzerland) to identify BNYVV. The optical density was measured at $405 \mathrm{~nm}$ using the micropleyt reader (Tecan Spectra II, Austria) and a sample was considered as positive when absorbance value at $405 \mathrm{~nm}$ was more than two times the mean of the negative control (Meunier et al. 2003).

\section{Reverse transcription polymerase chain reaction (RT-PCR)}

Total nucleic acids were extracted from $100 \mathrm{mg}$ of roots from cv. Arosa using an RNeasy Plant Mini Kit (Qiagen, Germany) as described in the manufacturer's instructions. One-step reverse transcription polymerase chain reaction (RT-PCR) was performed as described in the manufacturer's manual (Qiagen, USA) using thermocycler (Bio-Rad, USA) for BNYVV RNA-2 and RNA-3. For the detection of BNYVV RNA-2 and RNA-3, the primers proposed by Kruse et al. (1994) were used (BNYVV-2F: CCATTGAATAGAATTTCACC and BNYVV-2R: CCCCATAGTAATTTTAACTC for BNYVV RNA-2; BNYVV-3F: GTGATATATGTGAGGACGCT and BNYVV-3R: CCGTGAAATCAC-GTGTAGTT for BNYVV RNA-3). The RT-PCR reaction was done as follows: 10.5 $\mu \mathrm{l}$ RNase-free water, $5 \mu \mathrm{l}$ 5X Qiagen OneStep RT-PCR buffer, $1 \mu \mathrm{l}$ dNTPs mix (400 $\mu \mathrm{M}), 5 \mu \mathrm{l} 5 \mathrm{X}$ solution, $0.25 \mu \mathrm{l}$ each of forward and reverse primers $(0.6 \mu \mathrm{M}), 1 \mu \mathrm{l}$ Qiagen OneStep RT-PCR Enzyme mix and $2 \mu \mathrm{l}$ RNA sample were added to the mixture. Reverse transcription of $30 \mathrm{~min}$ at $50^{\circ} \mathrm{C}$ and $15 \mathrm{~min}$ at $95^{\circ} \mathrm{C}$ was performed. Then 35 cycles composed of denaturation for $30 \mathrm{~s}$ at $94^{\circ} \mathrm{C}$, annealing for $30 \mathrm{~s}$ at $41^{\circ} \mathrm{C}$ for RNA-2 (30 $\mathrm{s}$ at $48^{\circ} \mathrm{C}$ for RNA-3), and elongation for $1 \mathrm{~min}$ at $72^{\circ} \mathrm{C}$, were carried out. A final elongation of $7 \mathrm{~min}$ at $72^{\circ} \mathrm{C}$ was added.

One-step RT-PCR was performed using a Superscript ${ }^{\circledR}$ III One-Step RT-PCR System with Platinum Taq DNA polymerase kit (Invitrogen) using thermocycler (Bio-Rad, USA) for BNYVV RNA-5. The upstream (BN5/F1: GTTTTTCCGCTCGCACAAGCG) and the downstream (BN5/R1: CGAGCCCGT-AAACACCGCATA) primers (Schirmer et al. 2005) which are specific for RNA-5 were used. The RT-PCR reaction was done as follows: 9.5 $\mu \mathrm{l}$ RNase-free water, $12.5 \mu \mathrm{l} 2 \mathrm{X}$ reaction buffer, $0.5 \mu \mathrm{l}$ each of forward and reverse primers $(10 \mu \mathrm{M}), 1 \mu \mathrm{l}$ Superscript III RT/Platinum Taq mix and $1 \mu \mathrm{l}$ RNA sample were added to the mixture. The following reaction conditions were conducted: $55^{\circ} \mathrm{C}$ for $30 \mathrm{~min}$ and $94^{\circ} \mathrm{C}$ for $2 \mathrm{~min}$ followed by 40 cycles of $94^{\circ} \mathrm{C}$ for $15 \mathrm{~s}, 59^{\circ} \mathrm{C}$ for $30 \mathrm{~s}, 68^{\circ} \mathrm{C}$ for $1 \mathrm{~min}$, and final elongation step for $5 \mathrm{~min}$ at $68^{\circ} \mathrm{C}$.

The samples were analyzed on 1\% ethidium bromide agarose gel in $1 \mathrm{X}$ Tris-borate-EDTA (TBE) buffer using the Gel Doc 2000 Systems (Bio-Rad, USA).

\section{RFLP analysis for the characterization of BNYVV strain types}

Twenty isolates were used for RLFP analysis (Table1). The primers BNYVV-2F and BNYVV-2R; BNYVV-3F and BNYVV-3R were used to amplify the RNA-2 (nt. 19-1088) and RNA-3 (nt. 50-1268), respectively and followed by restriction cut with enzymes EcoRI and EcoRI, BamHI, StyI. Digestions were done as previously described by Kruse et al. (1994) and the restrictions patterns were analyzed by electrophoresis in $1 \%$ agarose gel stained with ethidium bromide.

\section{Results}

\section{Detection of BNYVV}

In a previous study, BNYVV was detected in 156 of the 510 sugar beet fields in the northern and central parts of Turkey (Kutluk Yilmaz and Arli-Sokmen, 2010). In the bait plant test with BNYVV-positive soil samples, sugar beet seedlings of rhizomania susceptible cv. Arosa showed different kinds of virus symptoms such as chlorosis, leaf rolling+curling, green vein banding + distortion, necrotic lesions and chlorotic lesions+chlorosis in growth room conditions (Table 1). Besides this, these kind of symptoms were not detected all plants, some of BNYVV-infected plants gave no visible symptom. The presence of some symptomatic differences in bait plant tests raises the question whether different BNYVV strain types are present in this region. Therefore, a total of twenty BNYVV-infested soil samples were selected according to their symptom expression and geographic origin from northern and central parts of Turkey. The rhizomania susceptible (cv. Arosa) cultivar was grown in these soils. To confirm of the presence of BNYVV in bait plant samples, DAS-ELISA test was done. All of the samples tested were positive in ELISA for BNYVV (Figure 1; Table 2). 
Table 2. The presence of BNYVV and characterization of BNYVV strain types in northern and central parts of Turkey.

\begin{tabular}{llcccc}
\hline Province & District & Isolate No & $\begin{array}{c}\text { ELISA absorbance } \\
\text { values }\end{array}$ & $\begin{array}{c}\text { RFLP } \\
\text { pattern }\end{array}$ & $\begin{array}{c}\text { RNA-5 } \\
\text { positive* }\end{array}$ \\
\hline Amasya & Centrum & 178 & $1.246(+)$ & $\mathrm{A}$ & - \\
& Suluova & 175 & $0.537(+)$ & $\mathrm{A}$ & - \\
& Tasova & 186 & $0.339(+)$ & $\mathrm{A}$ & - \\
& Tasova & 249 & $2.743(+)$ & $\mathrm{A}$ & - \\
Cankiri & Kizilirmak & 164 & $0.469(+)$ & $\mathrm{A}$ & - \\
Corum & Iskilip & 114 & $0.400(+)$ & $\mathrm{A}$ & - \\
& Osmancik & 106 & $0.747(+)$ & $\mathrm{A}$ & - \\
& Ssmancik & 150 & $0.997(+)$ & $\mathrm{A}$ & + \\
Kastamonu & Sarayovasi & 176 & $0.364(+)$ & $\mathrm{A}$ & - \\
Samsun & Bafra & 421 & $0.317(+)$ & $\mathrm{A}$ & + \\
& Kavak & 40 & $0.243(+)$ & $\mathrm{A}$ & + \\
& Vezirkopru & 30 & $1.017(+)$ & $\mathrm{A}$ & - \\
Tokat & Vezirkopru & 85 & $0.217(+)$ & $\mathrm{A}$ & - \\
& Artova & 325 & $2.927(+)$ & $\mathrm{A}$ & - \\
& Erbaa & 103 & $0.343(+)$ & $\mathrm{A}$ & - \\
& Erbaa & 291 & $2.829(+)$ & $\mathrm{A}$ & - \\
& Niksar & 202 & $2.911(+)$ & $\mathrm{A}$ & - \\
& Niksar & 275 & $2.820(+)$ & $\mathrm{A}$ & - \\
& Pazar & 210 & $2.782(+)$ & $\mathrm{A}$ & - \\
& Zile & 262 & $2.837(+)$ & $\mathrm{A}$ & - \\
\hline Total (\%) & Zile & 324 & $0.600(+)$ & $\mathrm{A}$ & $4(\% 20)$ \\
\hline
\end{tabular}

*+: determined; -: not determined.

\section{RFLP analyses of BNYVV isolates}

RT-PCR studies were done by using the primers specific to RNA-2 (nt. 19-1088) and RNA-3 (nt. 50-1268). RFLP analysis of the PCR products revealed that BNYVV isolates in the region were A-type strain (Figure 2, 3 and 4), despite two isolates (421 and $186 \mathrm{No}$ ) did not exactly fit the band profile of A type isolates (Figure 3). The isolate 421 gave no visible symptom on sugar beet seedlings (cv. Arosa) in bait plant test, whereas the isolate 186 showed green vein banding and leaf deformation (Table 1). Besides this, no BNYVV B-type infections were found in the region (Table 2).

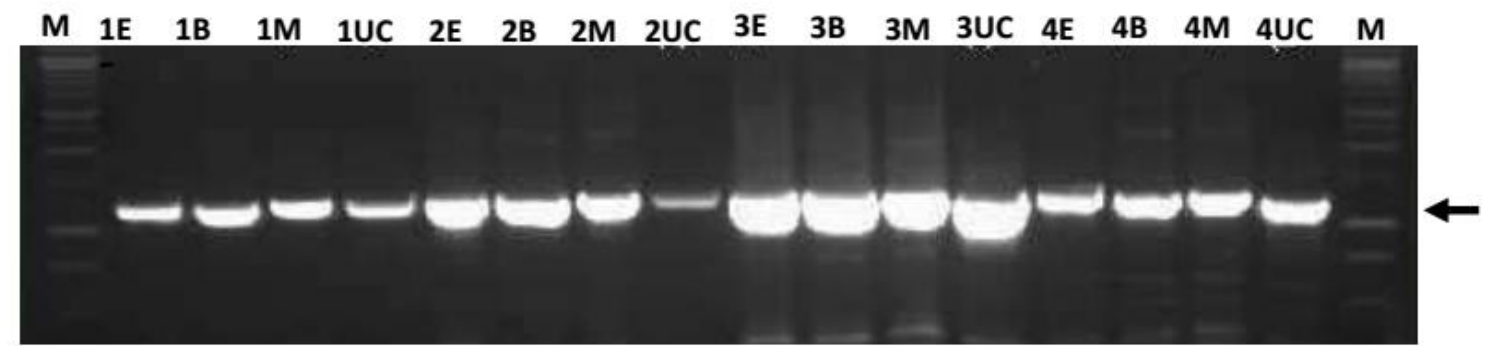

Figure 2. RLFP analysis for RNA-3 of Turkish BNYVV isolates. M: 1kb DNA Ladder (Promega, USA). The black arrow indicates BNYVV-specific 1218-bp DNA fragment. Lane 1-4, from a bait plant grown in the soil sample No. 178; lane 5-8 from a bait plant in the soil sample No. 262; lane 9-12, from a bait plant grown in the soil sample No. 325; lane 13-16, from a bait plant in the soil sample No. 175. E: EcoRI, B: BamHI, M: MspI, UC: Uncut PCR product.

\section{Detection of BNYVV RNA-5}

To test whether the samples involves the fifth RNA segment, they were subjected to RT-PCR analysis with BNYVV RNA-5 specific primers (Schirmer et al. 2005). Four BNYVV-positive samples (20\%) produced the expected amplicon of $885 \mathrm{bp}$ in PCR amplification by using BN5/F1 and BN5/R1 primers (Data not shown). In this study, RNA-5 was determined in Corum, Samsun and Tokat provinces (Figure 1 and Table 1). This result indicated that BNYVV isolates containing RNA-5 segment seems to be not located in this region. The BNYVV isolates (40, 103 and 150) with RNA-5 showed light chlorosis and chlorotic lesions+chlorosis types of symptom on sugar beet seedlings in bait plant tests, whereas the isolate (412) gave no visible symptom (Table 1). 


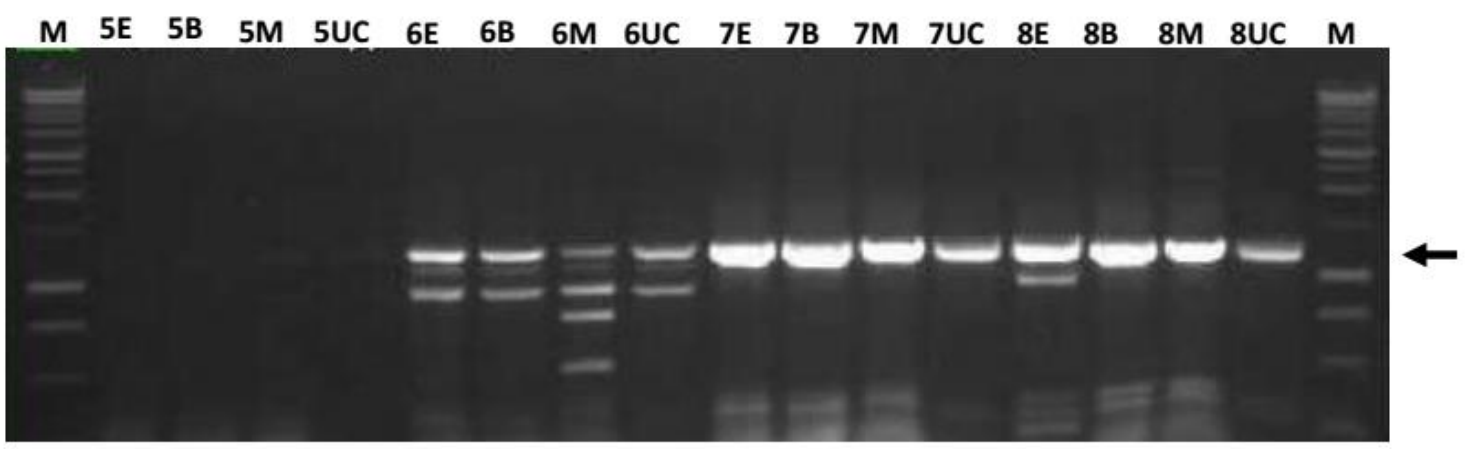

Figure 3. RLFP analysis for RNA-3 of Turkish BNYVV isolates. M: 1kb DNA Ladder (Promega, USA). The black arrow indicates BNYVV-specific 1218-bp DNA fragment. Lane 1-4, from a bait plant grown in the soil sample No. 275; lane 5-8 from a bait plant in the soil sample No. 421; lane 9-12, from a bait plant grown in the soil sample No. 106; lane 13-16, from a bait plant in the soil sample No. 186. E: EcoRI, B: BamHI, M: MspI, UC: Uncut PCR product.

M 1E 1UC 2E 2UC 3E 3UC 4E 4UC 5E 5UC 6E 6UC 7E 7UC 8E 8UC 9E 9UC M

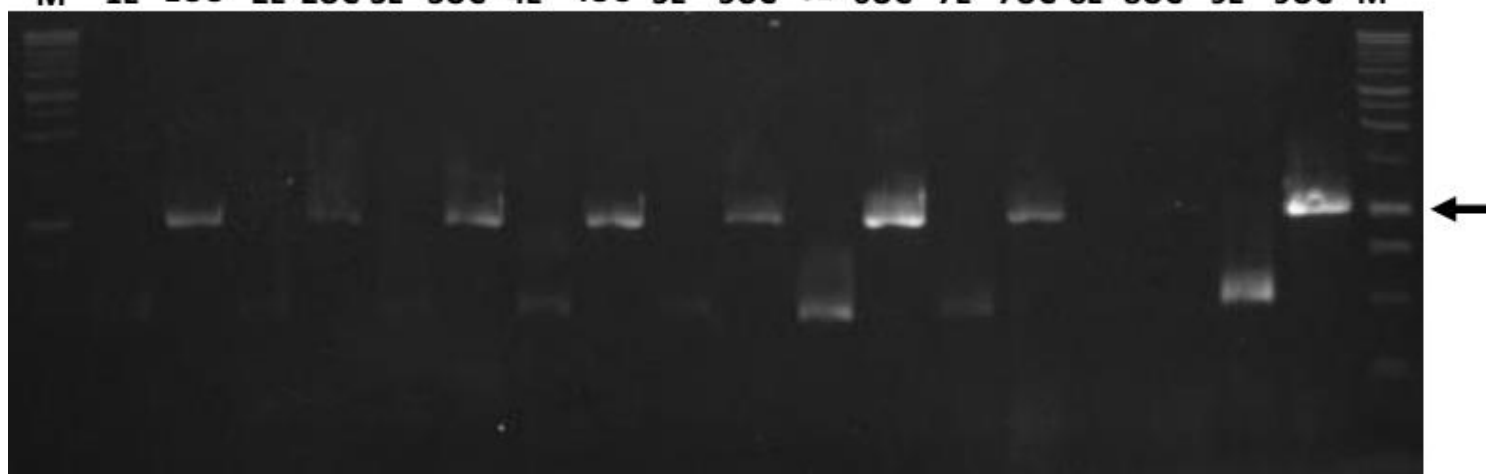

Figure 4. RLFP analysis for RNA-2 of Turkish BNYVV isolates. M: 1kb DNA Ladder (Promega, USA). The black arrow indicates BNYVV-specific 1070-bp DNA fragment. Lane 1-2, from a bait plant grown in the soil sample No. 186; lane 3-4 from a bait plant in the soil sample No. 178; lane 5-6 from a bait plant grown in the soil sample No. 106; lane 7-8, from a bait plant in the soil sample No. 85; lane 9-10 from a bait plant grown in the soil sample No. 325; lane 11-12 from a bait plant grown in the soil sample No. 291; lane 13-14 from a bait plant grown in the soil sample No. 175; E: EcoRI, UC: Uncut PCR product.

\section{Discussion}

In the current study, RFLP analysis was conducted for strain determination (A and B type) of BNYVV isolates selected according to their geographic origin and symptom expressions such as chlorosis, leaf rolling+curling, green vein banding+distortion, necrotic lesions and chlorotic lesions+chlorosis (Table 1) in bait plants grown in soils from northern and central parts of Turkey (Figure 1). Restriction patterns obtained for all BNYVV isolates were identical to A-type strain, despite two isolates (421 and 186) did not exactly fit the band profile of A-type isolates (Figure 3, Table 2). These isolates may differ in polymorphic sites and could be different variants of BNYVV. Polymorphism may further be investigated by sequencing. Interestingly, the isolate 421 gave no visible symptom on sugar beet seedlings (cv. Arosa) in bait plant tests, whereas the isolate 186 showed green vein banding and leaf deformation (Table 1). Similarly, A-type BNYVV have been previously reported in Turkey (Kruse et al. 1994; Kutluk Yilmaz et al. 2007; Chiba et al. 2011; Kutluk Yilmaz et al. 2016) and in its neighboring counties for example Iran (Sohi and Melaki, 2004) and Greece (Kruse et al. 1994; Pavli et al. 2011). No B-type BNYVV infections were found in tested samples in the region whereas the B-type BNYVV (Sohi and Maleki, 2004) was recorded in Iran.

Additionally, BNYVV RNA-5 segment was detected in four samples belonging to Corum, Samsun and Tokat provinces (Figure 1 and Table 2). In a previous study, Kutluk Yilmaz et al. (2016) indicated that BNYVV populations containing RNA-5 is highly widespread in sugar beet production areas in Turkey. Besides this, nucleotide sequencing and phylogenetic analyses showed that RNA-5 of Turkish BNYVV isolates is closer to the J-type BNYVV isolates than the P-type isolates (Kutluk Yilmaz et al. 2016). On the other hand, the J-type widely distributed in Asia (Tamada et al. 1989; Li et al. 2008) whereas it was recorded in a field of Germany (Koenig et al. 2008). 
From RNAs of BNYVV, the RNA-3 encoded p25 controls rhizomania symptoms in sugar beet roots and severe symptom expression in Chenopodiaceae hosts (Tamada et al. 1999; Jupin et al. 1992). Besides this, the severity of symptoms in sugar beet was increased by the additional presence of RNA-5 (Tamada et al. 1996; Miyanishi et al. 1999). In this study, two of RNA-5 containing isolates (40 and 103) showed chlorosis type of symptom on the susceptible cv. Arosa, whereas the isolate 150 gave chlorotic lesions+chlorosis type of symptom. Also, the isolate 421 (with RNA-5 segment) gave no visible symptom (Table 1) and its obtained restriction patterns did not exactly fit the band profile of A-type isolates (Figure 3). In the previous study, chlorosis type of symptom has been typically associated with BNYVV (Rush et al. 2006). Also they indicated that some BNYVV-infected plants never exhibited foliar symptoms. Similarly, in the current study, some of BNYVV-infected plants gave no visible symptom (Table 1). On the other hand, it is known that high soil $\mathrm{pH}$ and lime $\left(\mathrm{CaCO}_{3}\right)$ contents cause chlorosis by affecting nutrient sufficiency in soils (Kutluk and Arli Sokmen, 2007). Kutluk Yilmaz et al. (2010) reported that increasing lime and exchangeable Mg contents of soils increased soil $\mathrm{pH}$ and induced BNYVV and Beet soil-borne virus (BSBV) infections transmitted by vector $P$. betae, respectively. There are very few published studies about different infection phenotypes of BNYVV populations on sugar beet. Some researchers indicated that the resistant plants after rub inoculation displayed a range of symptoms from no visible lesion or necrotic lesions at the inoculation site, whereas the susceptible plants showed bright yellow lesions (Chiba et al. 2008).

Consequently, the majority of the samples contained A-type BNYVV (80\%), but in $20 \%$ of the samples, Atype BNYVV with RNA-5 was identified. There was no any interaction found between symptom expression and strain types of BNYVV populations. Moreover, RNA-5 segment did not seem to be directly associated with symptom severity on sugar beet seedlings (rhizomania susceptible cv. Arosa) in bait plants in this study.

\section{Acknowledgements}

We would like to thank for the financial support to The Scientific and Technological Research Council of Turkey (TUBITAK, Project No: TOGTAG 1080585).

\section{References}

Abe, H., Tamada, T., 1986. Association of Beet Necrotic Yellow Vein Virus with isolates of Polymyxa betae Keskin. Annals of Phytopathological Society of Japan 52(2): 235-247.

Akca, I., Kutluk Yilmaz, N.D., Kizilkaya, R., 2005. Effects of azadirachtin on Beet soilborne pomovirus and soil biological properties on sugar beet. Journal of Environmental Science and Health, Part B, Pesticides Food Contaminants and Agricultural Wastes 40 (2): 285-296.

Akca, I., Kutluk Yilmaz, N.D., Kizilkaya, R., 2014. Evaluation of suppression of rhizomania disease by earthworm (Lumbricus terrestris L.) and its effects on soil microbial activity in different sugar beet cultivars. Archives of Agronomy and Soil Science 60 (11): 1565-1575.

Bürcky, K., Büttner, G., 1985. Ansätze zur Selektion rizomaniatoleranter Zuckerrüben während der Jugendentwicklung. I: Virustiter. Zuckerindustrie 110(11): 997-1000.

Burketova, L., Sindelarova, M., Rysanek, P., 1996. Induction of resistance of sugar beet plants to Polymyxa betae transmitted Beet necrotic yellow vein virus (BNYVV) by salicylic acid. Proceedings of the Third Symposium of the International Working Group on Plant Viruses with Fungal Vectors. West Park Conference Centre, Dundee, Scotland, 6-7 August, 1996. pp. 137-140.

Chiba, S., Miyanishi, M., Andika, I.B., Kondo, H., Tamada, T., 2008. Identification of amino acids of the beet necrotic yellow vein virus p25 protein required for induction of the resistance response in leaves of Beta vulgaris plants. Journal of General Virology 89: 1314-1323.

Chiba, S., Kondo, H., Miyanishi, M., Andika, I.B., Han, C., Tamada, T., 2011. The evolutionary history of beet necrotic yellow vein virus deduced from genetic variation, geographical origin and spread, and the breaking of host resistance. Molecular Plant-Microbe Interactions 24 (2): 207-218.

Clark, M.F., Adams, A.N., 1977. Characteristics of the microplate method of Enzyme Linked Immunosorbent Assay for the detection of plant viruses. Journal of General Virology 34: 475-483.

Jupin, I., Tamada, T., Richards, K., 1992. Pathogenesis of Beet necrotic yellow vein virus. Seminars in Virology 2: 121129.

Kaya, R., 2009. Distribution of rhizomania disease in sugar beet growing areas of Turkey. Journal of Agricultural Sciences 15 (4): 332-340.

Koch, F., 1987. Bericht über eine in verschiedene zuckerrübenanbaugebiete der Turkseker in Anatolien und Thrazien zum stadium von wurzelerkrankungen. KWS Kleinwanzlebener Saatzucht, AG, Einbeck, Germany.

Koenig, R., Lüddecke, P., Haeberlé, A.M., 1995. Detection of Beet necrotic yellow vein virus strains, variants and mixed infections by examining single-strand conformation polymorphisms of immunocapture RT-PCR products. Journal of General Virology 76: 2051-2055. 
Koenig, R., Lennefors, B.L., 2000. Moleculer analyses of European A, B and P type sources of Beet necrotic yellow vein virus and detection of the rare $\mathrm{P}$ type in Kazakhstan. Archives of Virology 145(8): 1561-1570.

Koenig, R., Kastirr, U., Holtschulte, B., Deml, G., Varrelmann, M., 2008. Distribution of various types and P25 subtypes of Beet necrotic yellow vein virus in Germany and other European countries. Archives of Virology 153(11): 21392144.

Kruse, M., Koenig, R., Hoffman, A., Kaufmann, A., Commandeur, U., Solevyev, A.G., Savenkov, I., Burgermeister, W., 1994. Restriction fragment length polymorphism analysis of reverse transcription-PCR products reveals the existence of two major strain groups of beet necrotic yellow vein virus. Journal of General Virology 75: 1835-1842.

Kutluk Yilmaz, N.D., Meunier, A., Schmit, J.F., Stas, A., Bragard, C., 2007. Partial nucleotide sequence analysis of Turkish isolates of Beet necrotic yellow vein virus (BNYVV) RNA-3. Plant Pathology 56(2): 311-316.

Kutluk Yilmaz, N.D., Arli Sokmen, M., 2007. The effects of soilborne sugar beet viruses and their vector Polymyxa betae Keskin on symptom expression and root weight of sugar beet. Journal of Turkish Phytopathology 36(1-3): 39-52

Kutluk Yilmaz, N.D., Arli Sokmen, M., 2010. Occurrence of soilborne sugar beet viruses transmitted by Polymyxa betae Northern and Central Parts of Turkey. Journal of Plant Pathology 92 (2): 497-500.

Kutluk Yilmaz, N.D., Sokmen, M., Gulser, C., Saracoglu, S., Yilmaz, D., 2010. Relationships between soil properties and soilborne viruses transmitted by Polymyxa betae Keskin in sugar beet fields. Spanish Journal of Agricultural Research 8 (3): 766-769.

Kutluk Yilmaz, N.D., Arli Sokmen, M., Kaya, R., Sevik, M.A., Tunali, B., Demirtas, S., 2016. The widespread occurrences of Beet soil borne virus and RNA-5 containing Beet necrotic yellow vein virus isolates in sugar beet production areas in Turkey. European Journal of Plant Pathology 144 (2): 443-435.

Li, M., Liu, T., Wang, B., Han, C.G., Li, D.W., Yu, J.L., 2008. Phylogenetic analysis of Beet necrotic yellow vein virus isolates from China. Virus Genes 36(2): 429-432.

Meunier, A., Schmit, J.F., Stas, A., Kutluk, N., Bragard, C., 2003. Multiplex reverse transcription for simultaneous detection of Beet necrotic yellow vein virus, Beet soilborne virus, and Beet virus $Q$ and their vector Polymyxa betae KESKIN on sugar beet. Applied and Environmental Microbiology 69 (4): 2356-2360.

Miyanishi, M., Kusume, T., Saito, M., Tamada, T., 1999. Evidence for three groups of sequence variants of beet necrotic yellow vein virus RNA 5. Archives of Virology 144(5): 879-892.

Pavli, O., Prins, M., Goldbach, R., Skaracis, G.N., 2011. Efficiency of Rz1-based rhizomania resistance and molecular studies on BNYVV isolates from sugar beet cultivation in Greece. European Journal of Plant Pathology 130: 133142.

Peltier, C., Hleibieh, K., Thiel, H., Klein, E., Bragard, C., Gilmer, D., 2008. Molecular biology of the Beet necrotic yellow vein virus. Plant Virology 2: 14-24.

Rahim, M.D., Andika, I.B., Han, C., Kondo, H., Tamada, T., 2007. RNA-4 encoded p31 of beet necrotic yellow vein virus is involved in efficient vector transmission, symptom severity and silencing suppression in roots. Journal of General Virology 88: 1611-1619.

Ratti, C., Clover, G.R.G., Autonell, C.R., Harju, V.A., Henry, C.M., 2005. A multiplex RT-PCR assay capable of distinguishing beet necrotic yellow vein virus types A and B. Journal of Virological Methods 124(1-2): 41-47.

Rush, C.M., Liu, H.Y., Lewellen, R.T., Acosta-Leal, R., 2006. The continuing saga of rhizomania of sugar beets in the United States. Plant Disease 90 (1): 4-15.

Schirmer, A., Link, D., Cognat, V., Moury, B., Beuve, M., Meunier, A., Bragard, C., Gilmer, D., Lemaire, $0 ., 2005$. Phylogenetic analysis of isolates of Beet necrotic yellow vein virus collected worldwide. Journal of General Virology 86: 2897-2911.

Sohi, H. H., Maleki, M., 2004. Evidence for presence of types A and B of Beet Necrotic Yellow Vein Virus (BNYVV) in Iran. Virus Genes 29 (3): 353-358.

Tamada, T., Shirako, Y., Abe, H., Saito, M., Kiguchi, T., Harada, T., 1989. Production and pathogenicity of isolates of beet necrotic yellow vein virus with different numbers of RNA components. Journal of General Virology 70: 33993409.

Tamada, T., Kusume, T., Uchino, H., Kiguchi, T., Saito, M., 1996. Evidence that Beet necrotic yellow vein virus RNA 5 is involved in symtom development of sugar beet roots. Proceedings of the Third Symposium of the International Working Group on Plant Viruses with Fungal Vectors. West Park Conference Centre, Dundee, Scotland, 6-7 August, 1996. pp 49-52.

Tamada, T., 1999. Benyviruses: In: Encyclopedia of Virology. Webster, R.G., Granoff, A. (Eds.). 2 nd edition. Academic, London, pp.154-160.

Tamada, T., Uchino, H., Kusume, T., Saito, M., 1999. RNA 3 deletion mutants of beet necrotic yellow vein virus do not cause rhizomania disease in sugar beets. Phytopathology 89: 1000-1006.

Ward, L., Koenig, R., Budge, G., Garrido, C., McGrath, C., Stubbey, H., Boonham, N., 2007. Occurrence of two different types of RNA-5 containing beet necrotic yellow vein virus in the UK. Archives of Virology 152: 59-73.

Wang, Q., Wang, H., Yu, J., Liu, Y., 2003. Screening of actinomyces against Polymyxa betae and detection of effectiveness on rhizomania disease. Journal of South China Agricultural University 8: 56-60.

Yardimci, N., Culal-Kılıc, H., 2011. Identification of Beet necrotic yellow vein virus in lakes district: A major beet growing area in Turkey. Indian Journal of Virology 22 (2): 127-130. 